\title{
Comparison of old and local apple varieties and seedlings (Malus domestica Borkh.) in the variability of some morphological characters of fruits and seeds
}

\author{
Vladimíra Horčinová Sedláčková*1, Miloš Hulin ${ }^{1}$, Yulia Vinogradova², \\ Inna Goncharovska ${ }^{3}$, Ján Brindza ${ }^{1}$ \\ ${ }^{1}$ Slovak University of Agriculture in Nitra, Faculty of Agrobiology and Food Resources, \\ Institute of Biodiversity Conservation and Biosafety, Nitra, Slovakia \\ ${ }^{2}$ N.V. Tsitsin Main Botanical Garden of Russian Academy of Sciences, Moscow, Russia \\ ${ }^{3}$ M.M. Gryshko National Botanical Garden of the NAS of Ukraine, Kyiv, Ukraine
}

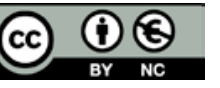

Article Details:

Received: 2021-03-10

Accepted: $\quad$ 2021-03-22

Available online: 2021-05-31

\begin{abstract}
Old and local varieties of cultivated plant species selected from natural populations adapted to long-term cultivation, which represent a rich genetic potential for the development of agroecosystems and agriculture under specific conditions, resources for an environment aestheticization, landscaping and development of cultural traditions. The research focused on determining the economic value of a selected collection of old and local varieties of apple tree (Malus domestica Borkh.), widespread in Slovakia for their practical use in organic farming or as genetic resources for breeding new varieties for organic food production. For experimental evaluation, we used two collections: 1) 73 old and local varieties of apple trees concentrated and preserved ex situ in a clone repository in the village Bacúch; 2) 77 self-sown seedlings, that spontaneously emerged as a result of free pollination and are growing in situ around Nitra, Levice, Nové Zámky, Šal'a, Galanta, Hlohovec, Piešt’any, Prievidza, Partizánske, Zlaté Moravce. We determined for all specimens the range for the weight of fruits 53.63-207.40/16.13-197.59 (g), height of fruits 41.47-72.93/ 29.55-74.04 (mm), diameter of fruits 51.46-84.66/36.85-78.43 (mm), length of core/13.16-27.36/11.24$25.86(\mathrm{~mm})$, diameter of core 18.26-33.46/13.72-30.86 (mm), weight of 10 seeds $0.38-0.77 / 0.29-0.98(\mathrm{~g})$, height of seeds 6.68-9.90/6.16-9.83 (mm), diameter of seeds 3.73-5.71/3.51-5.27 (mm). The results document that in both collections there are genotypes suitable for organic cultivation, and further selective improvement.
\end{abstract}

Keywords: Malus domestica, genetic resources, clone repository, morphometric analysis, variability

\section{Introducion}

The native range of apple tree (Malus domestica Borkh.) is difficult to determine, as the species is a product of domestication and multiple hybridizations across the world over thousands of years. In Slovakia, fruit growing has a long tradition. Apple trees have a dominant position in fruit growing. Malus domestica from the genus Malus from the family Rosaceae and the subfamily Pomoideae is an example of the most important, the most widespread and best adapted fruit tree of temperate zone in terms of production. Malus occupies a central place in the folklore, culture and art (Robinson et al., 2001; Harris et al., 2002; Juniper and Mabberley, 2006; Velasco et al., 2010).

A local variety is a domesticated, locally adapted, traditional variety of a species of plant that has developed over time, through adaptation to its natural and cultural environment of agriculture, and due to isolation from other populations of the species. Local varieties are generally distinguished from cultivars.

\footnotetext{
*Corresponding Author: Vladimíra Horčinová Sedláčková, Slovak University of Agriculture in Nitra, Faculty of Agrobiology and Food Resources, Institute of Biodiversity Conservation and Biosafety, Nitra, Slovakia $\triangle$ vladimira.sedlackova@uniag.sk
} 
They have been selected from natural populations and grown for nutritional use or other purposes. Due to their long-term cultivation in different areas, they have adapted to certain specific growing conditions, thus acquiring a high degree of tolerance against adverse environmental factors. Old cultivars and varieties are highly disease resistant to apple scab, powdery mildew, green apple aphid, apple codling moth in general (Militaru et al., 2015; Papp et al., 2015). Cultivation the less susceptible varieties is the most obvious way to reduce problems with pests and diseases; therefore, the choice of apple varieties for organic farming is extremely important. Great effort has been put into developing breeding programmes to create scab resistant varieties. However, older varieties that originated before the appearance of pesticides might be less susceptible than newer varieties and would thereby be a better choice for organic farming (Kühn et al., 2003; Militaru et al., 2015; Papp et al., 2015).

Regarding polyphenols, it is known that old and local apple varieties were characterized by a higher content of polyphenols and stronger antioxidant properties than commercial varieties, which enjoys a high growth rate, but unfortunately, these new varieties are characterized by a very low content of bioactive compounds, including polyphenolic compounds (Kuznetsova et al., 2017; Oszmiański et al., 2019). The consumption of such apple varieties may reduce the polyphenolic compounds in the dietary supply (Iacopini et al., 2010; Donno et al., 2012). Some studies presented the amounts of biologically active substances in old and new varieties were similar (Wojdyło et al., 2008). In the study of Feliciano et al. (2010), both traditional and exotic apple varieties from Portugal showed high amounts of polyphenols. It should be noted that environmental conditions can influence on the polyphenol amounts.

Local varieties represent the means of production for the development of agroecosystems and agriculture in specific conditions, resources for the aestheticization of the environment, landscaping and the development of cultural traditions (Brindza, 2001; Tóth et al., 2004; Ganopoulos et al., 2017). One of the largest collections of old apple varieties is located in a neighbouring Poland and Ukraine and spread over the territory of the then ancient Eastern Galicia in Central Europe (Dovbysh and Borodai, 2011; Żygala et al., 2011).

It is generally known that many local varieties, as well as cultivars, were selected from local self-sown individuals - seedlings (Boček, 2008a, 2008b; Hulin et al., 2012; Posolda et al., 2019). The establishment of clone repositories to save the endangered gene pool of plants has an application in our country for many fruit species such as pear, cherry, plum, chestnut, etc. (Bolvanský and Užík, 2012; Paprstein et al., 2013; Benediková et al., 2016). It is necessary to identify and evaluate genotypes based on the morphometrical and biochemical traits in various conditions, as evidenced by the many authors (Ivanišová et al., 2017; Vinogradova et al., 2017; Grygorieva et al., 2017a,b, 2018a,b; Fatrcová Šramková et al., 2019; Levon and Golubkova, 2019; Vergun et al., 2020).

This study aimed to evaluate the genetic resources of apple tree for organic farming in the collection of old and local varieties of Malus domestica Borkh. as well as self-sown seedlings widespread in Slovakia.

\section{Material and methodology}

\section{Biological material}

Two collections of biological material were used as genetic resources for the study:

1. Old and local varieties from different areas of Slovakia which are kept ex situ in a clone repository in the village Bacúch - 73 selected genotypes. In the experiments, samples were marked as $\mathrm{R}$ and the appropriate number.

2. Wild self-sown individuals - fruit-beraing seedlings from different localities (Nitra, Levice, Nové Zámky, Šala, Galanta, Hlohovec, Pieštany, Prievidza, Partizánske, Zlaté Moravce) in the form in situ - 77 selected genotypes. In the experiments, samples were marked as $\mathrm{S}$ and the appropriate number.

The total number of evaluated genotypes were 150 .

Fruits with peduncle were taken from treesinSeptember and October 2010 and analysed in the morphometric laboratory at the Institute of Biodiversity Conservation and Biosafety in Nitra (Slovakia).

\section{Morphometrical analysis}

They were evaluated the following characters:

a) fruits - 30 fruits were evaluated from each genotype $(\mathrm{n}=30)$, weight of fruit $(\mathrm{g})$, height of fruit $(\mathrm{mm})$, diameter of fruit $(\mathrm{mm})$, length of core (mm), diameter of core (mm), depth of stalk cavity ( $\mathrm{mm})$, depth of eye basin ( $\mathrm{mm})$;

b) seeds - 30 seeds were evaluated from each genotype $(\mathrm{n}=30)$, weight of 10 seeds $(\mathrm{g})$, height of seed $(\mathrm{mm})$, diameter of seed $(\mathrm{mm})$.

The weights were determined by digital scale (Kern ADB-A01S05, Germany; KERN DS - type D-72336, 


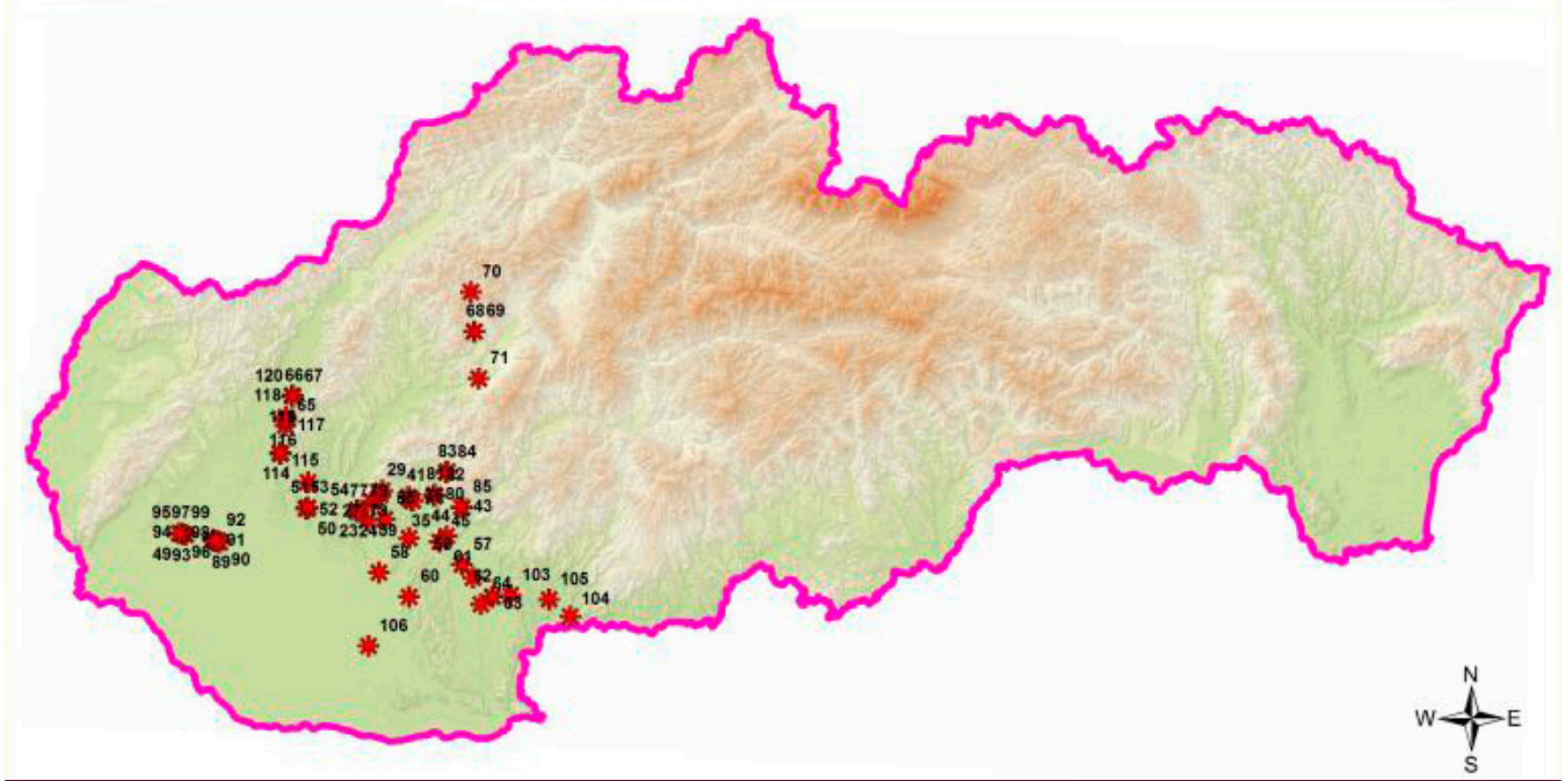

Figure 1 Localization of local varieties and seedlings of Malus domestica Borkh. within Slovakia using GPS: the detailed data can be found in Table 1

Table 1 Localities of varieties and seedlings Malus domestica Borkh. in Slovakia and their altitude

\begin{tabular}{|l||c|c|c|}
\hline Genotype & Locality & Region of Slovakia & Altitude, m a.s.l. \\
\hline \hline R01-R77 & Bacúch & central Slovakia & $590-630$ \\
\hline S01-S10 & Nitra & western Slovakia & 167 \\
\hline S11-S20 & Levice & south-western Slovakia & 165 \\
\hline S21-S30 & Nové Zámky & south-western Slovakia & 114 \\
\hline S31-S40 & Šal'a & south-western Slovakia & 116 \\
\hline S41-S50 & Galanta & south-western Slovakia & 119 \\
\hline S51-S60 & Hlohovec & western Slovakia & 146 \\
\hline S61-S70 & Pieštany & western Slovakia & 160 \\
\hline S71-S80 & Prievidza & western Slovakia & 309 \\
\hline S81-S90 & Partizánske & western Slovakia & 190 \\
\hline S91-S99 & Zlaté Moravce & western Slovakia & 192 \\
\hline
\end{tabular}

Note: altitude - meters above sea level

Kern and Sohn $\mathrm{GmbH}$, Germany), accurate to $0.01 \mathrm{~g}$. Fruits and seeds were measured by a digital calliper (METRICA 111 - 012, Czech Republic) accurate to $0.02 \mathrm{~mm}$.

\section{Image analysis}

1. Fruit: the shape of the fruit, the shape of the apical part of the fruit (at the stalk), depth of stalk cavity, depth of eye basin, the shape of the basal part of the fruit, basic colour of the skin at the full maturity, the colour of the pulp of ripe fruit.

2. Seeds: the shape of seeds.
Images were obtained using the stereomicroscope ZEISS SteREO Discovery.V20 (Microlmaging GmbH 37081 Göttingen, Germany), and Fuji FinePix S 7000 and Panasonic DMC FZ50 digital cameras.

\section{Statistical analysis}

It was evaluated the variability of each character using descriptive statistics. For the characteristics it was used the basic descriptors of variability: average, minimum measured value, maximum measured value, the coefficient of variation (\%). The degree of variability was determined by the coefficient of variation values. 

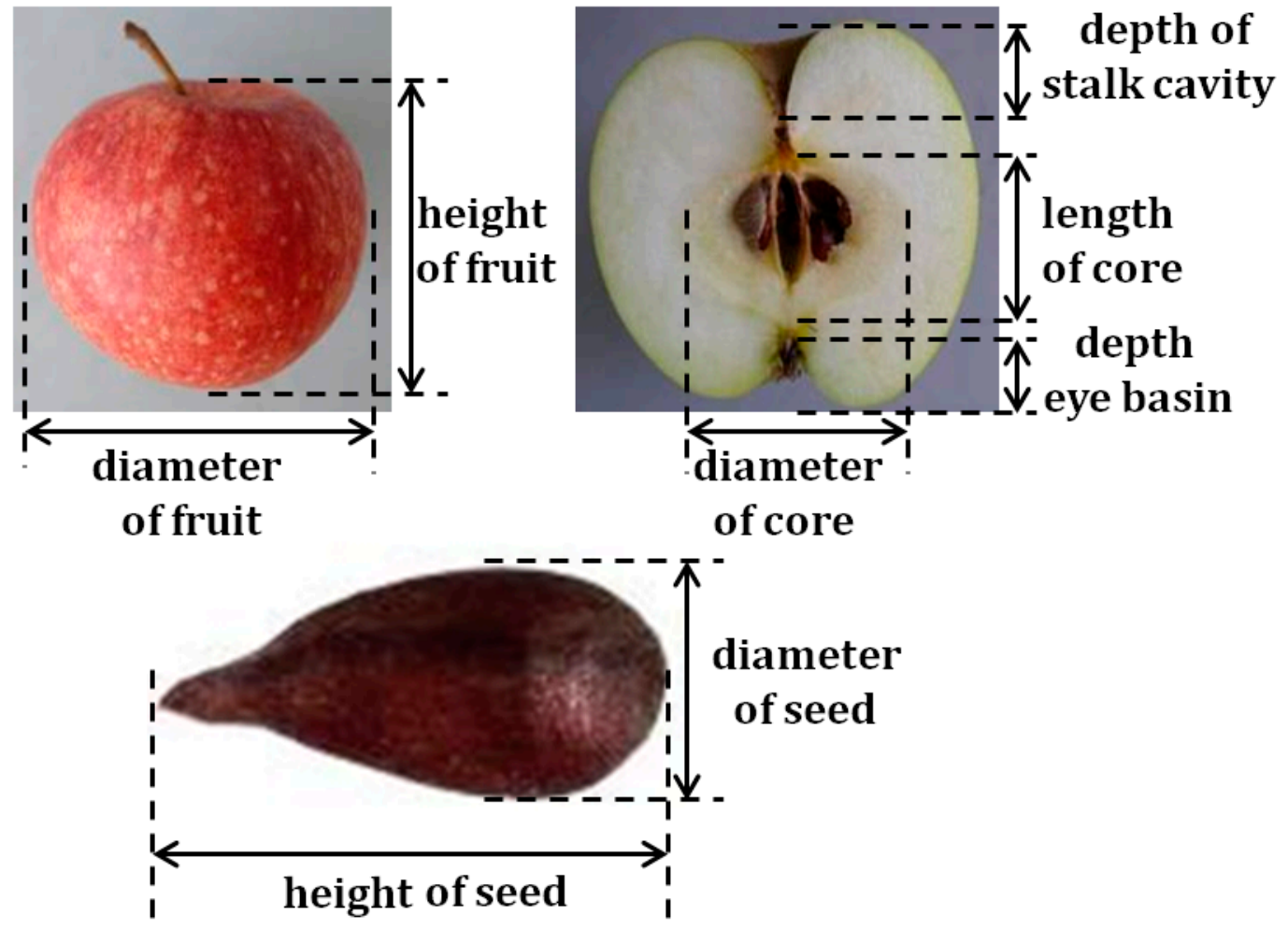

Figure 2

Illustration of measuring process: fruit height and diameter, core length and diameter, depth of stalk cavity and depth of eye basin

The given parameter is independent of the unit of the evaluated character. Theoretically, they can acquire different values (Stehlíková, 1998). We used analysis of variance (ANOVA) in the program STATISTICA 1.10 to determine the dependence between individual characters.

\section{Results and discussion}

Evaluation and identification of genotypes based on morphological traits are important for the detection and selection of individuals that are suitable genetic material for hybridization and breeding program of new varieties, which contributes to the global conservation of biological diversity (Monka et al., 2014; Grygorieva et al., 2017a,b, 2018a,b; Motyleva et al., 2017, 2018; Ivanišová et al., 2017; Vinogradova et al., 2017; Brindza et al., 2018, 2019; Fatrcová-Šramková et al., 2019; Horčinová Sedláčková et al., 2020).

\section{Morphometrical analysis of fruits}

When evaluating the genotypes under study (Table 2), the average weight of the fruits has been determined in the range of $3.63 \mathrm{~g}(\mathrm{R} 18 / 9)-207.40 \mathrm{~g}$ (R30/7)/16.13 g (S12) - $197.59 \mathrm{~g}$ (S03). The coefficients of variation were determined in the range of 4.18 (R33/12) - 17.02 (R18/7) \%/11.08 (S38) - 40.61 (S22) \%. These data demonstrate that the characters are from the low to very high degree of variability. The above comparisons show that it is possible to search for genotypes with the required fruit size in the populations of wild seedlings.

The differences in the weight of tested varieties were significant, and that is in full compliance with the studies assortment of old apple varieties from Denmark 77-205 g (Kühn et al., 2003), Montenegro 62.23-182.34 g (Božović et al., 2013), Croatia 26-325 g (Jakobek et al., 2020), Romania 117.0-186.5 g (Mitre et al., 2015), Bosnia and Herzegovina 63.77-208.97 g (Stanivuković et al., 2017).

Dvořák et al. (1976) classified fruits according to 3 -years-old average weight as extremely small (below $15 \mathrm{~g}$ ); very small (16-48 g); small (49-70 g); smaller (71-110 g); medium (111-150 g); larger (151-200 g); large (201-250 g); very large (251-350 g) and extremely large (above 351 g). Michálek (2003) divides apple varieties according to the size of the fruit while declaring the size of the fruit according to the dimensions - height and diameter of the fruit at the place of the largest diameter. According to the given descriptor, it recognizes smaller fruits - the average transverse diameter is up to $55 \mathrm{~mm}$, medium-sized (55-70 $\mathrm{mm})$, large fruits (71-85 $\mathrm{mm}$ ) and very large fruits (more than $85 \mathrm{~mm}$ ). According to the above 
Agrobiodivers Improv Nutr Health Life Qual, 5, 2021(1): 55-71

Table 2 Variability of fruits of old and local varieties of Malus domestica Borkh.

\begin{tabular}{|c|c|c|c|c|c|c|c|c|c|c|c|c|c|}
\hline \multicolumn{14}{|c|}{ Weight of fruits (g) } \\
\hline & \multicolumn{6}{|c|}{ Seedlings } & \multicolumn{7}{|c|}{ Genotypes from repository Bacúch } \\
\hline & $\mathbf{n}$ & $\min$ & $\max$ & $\overline{\mathbf{x}}$ & $\mathbf{V}$ & $\mathbf{H}$ & & $\mathbf{n}$ & $\min$ & $\max$ & $\overline{\mathbf{x}}$ & $\mathbf{V}$ & $\mathbf{H}$ \\
\hline \multicolumn{14}{|c|}{ Genotypes with low values } \\
\hline S12 & 30 & 12.20 & 20.50 & 16.13 & 18.83 & $\mathrm{k}$ & $\mathrm{R} 18 / 9$ & 30 & 47.7 & 59.7 & 53.63 & 7.59 & g \\
\hline S69 & 30 & 30.00 & 45.00 & 36.45 & 11.95 & $\mathrm{j}$ & R35/10 & 30 & 50.7 & 70.1 & 59.36 & 11.13 & $f$ \\
\hline \multicolumn{14}{|c|}{ Genotypes with high values } \\
\hline S03 & 30 & 142.90 & 331.00 & 197.59 & 28.25 & $\mathrm{a}$ & $\mathrm{R} 30 / 7$ & 30 & 170.5 & 241.5 & 207.40 & 11.76 & a \\
\hline S20 & 30 & 86.90 & 215.50 & 185.28 & 20.75 & $\mathrm{a}$ & R16/12 & 30 & 168.4 & 205.4 & 187.39 & 6.53 & $\mathrm{ab}$ \\
\hline \multicolumn{14}{|c|}{ Height of fruits (mm) } \\
\hline & \multicolumn{6}{|c|}{ Seedlings } & \multicolumn{7}{|c|}{ Genotypes from repository Bacúch } \\
\hline \multicolumn{14}{|c|}{ Genotypes with low values } \\
\hline S12 & 30 & 27.40 & 32.30 & 29.55 & 5.60 & $\mathrm{e}$ & $\mathrm{R} 33 / 12$ & 30 & 38.70 & 43.70 & 41.47 & 3.33 & $\mathrm{~d}$ \\
\hline S69 & 30 & 33.60 & 39.30 & 36.38 & 4.70 & ed & $\mathrm{R} 1 / 4$ & 30 & 41.5 & 44.6 & 42.86 & 1.86 & $\mathrm{~d}$ \\
\hline \multicolumn{14}{|c|}{ Genotypes with high values } \\
\hline S22 & 30 & 59.30 & 87.90 & 74.04 & 14.08 & $\mathrm{a}$ & $\mathrm{R} 30 / 7$ & 30 & 66.70 & 78.50 & 72.93 & 5.70 & $\mathrm{a}$ \\
\hline S03 & 30 & 58.60 & 83.40 & 67.91 & 12.03 & $\mathrm{a}$ & $\mathrm{R} 30 / 8$ & 30 & 62.20 & 80.50 & 71.32 & 9.03 & $\mathrm{a}$ \\
\hline \multicolumn{14}{|c|}{ Diameter of fruits (mm) } \\
\hline & \multicolumn{6}{|c|}{ Seedlings } & \multicolumn{7}{|c|}{ Genotypes from repository Bacúch } \\
\hline \multicolumn{14}{|c|}{ Genotypes with low values } \\
\hline S12 & 30 & 33.50 & 40.00 & 36.85 & 6.03 & $\mathrm{f}$ & $\mathrm{R} 18 / 9$ & 30 & 48.90 & 54.20 & 51.46 & 3.71 & $\mathrm{e}$ \\
\hline V69 & 30 & 43.10 & 50.10 & 45.67 & 5.57 & $\mathrm{e}$ & $\mathrm{R} 22 / 3$ & 30 & 49.00 & 53.80 & 51.58 & 2.94 & $\mathrm{e}$ \\
\hline \multicolumn{14}{|c|}{ Genotypes with high values } \\
\hline S03 & 30 & 72.60 & 95.10 & 78.43 & 8.12 & $\mathrm{a}$ & R30/8 & 30 & 76.30 & 90.90 & 84.66 & 6.56 & $\mathrm{a}$ \\
\hline S20 & 30 & 59.30 & 83.50 & 77.86 & 8.86 & $\mathrm{a}$ & $\mathrm{R} 16 / 12$ & 30 & 80.20 & 84.30 & 82.41 & 1.75 & $\mathrm{a}$ \\
\hline \multicolumn{14}{|c|}{ Depth of stalk cavity (mm) } \\
\hline & \multicolumn{6}{|c|}{ Seedlings } & \multicolumn{7}{|c|}{ Genotypes from repository Bacúch } \\
\hline \multicolumn{14}{|c|}{ Genotypes with low values } \\
\hline S24 & 30 & 0.00 & 5.30 & 2.04 & 83.00 & $\mathrm{~cd}$ & $\mathrm{R} 22 / 3$ & 30 & 0.00 & 3.60 & 1.67 & 67.63 & $\mathrm{e}$ \\
\hline S12 & 30 & 1.00 & 4.40 & 2.96 & 34.28 & $\mathrm{~cd}$ & R1/12 & 30 & 4.20 & 6.40 & 5.36 & 16.29 & $\mathrm{~d}$ \\
\hline \multicolumn{14}{|c|}{ Genotypes with high values } \\
\hline S20 & 30 & 11.30 & 18.80 & 16.11 & 12.66 & $\mathrm{a}$ & R14/11 & 30 & 13.20 & 16.30 & 14.82 & 6.83 & $\mathrm{a}$ \\
\hline S30 & 30 & 8.90 & 17.80 & 14.44 & 17.50 & $\mathrm{a}$ & R27/11 & 30 & 9.20 & 16.60 & 13.77 & 18.17 & $\mathrm{~b}$ \\
\hline \multicolumn{14}{|c|}{ Depth of eye basin (mm) } \\
\hline & \multicolumn{6}{|c|}{ Seedlings } & & & ypes fr & m repos & tory Bac & ch & \\
\hline & & & & & Gen & pes & ith low v & & & & & & \\
\hline S38 & 30 & 0.70 & 2.60 & 1.22 & 52.24 & $\mathrm{~d}$ & R18/9 & 30 & 1.20 & 3.20 & 2.10 & 33.14 & c \\
\hline S08 & 30 & 0.50 & 2.90 & 1.23 & 56.33 & $\mathrm{~d}$ & R33/12 & 30 & 1.10 & 3.10 & 2.17 & 26.16 & c \\
\hline & & & & & Genc & pes & ith high v & les & & & & & \\
\hline S22 & 30 & 8.10 & 18.10 & 11.69 & 29.09 & $\mathrm{a}$ & R3/16 & 30 & 7.20 & 10.00 & 8.86 & 9.77 & $\mathrm{a}$ \\
\hline S20 & 30 & 4.80 & 19.20 & 9.58 & 39.18 & $\mathrm{~b}$ & R16/14 & 30 & 7.60 & 9.50 & 8.60 & 6.71 & $\mathrm{a}$ \\
\hline
\end{tabular}


Table 2 continued

\begin{tabular}{|c|c|c|c|c|c|c|c|c|c|c|c|c|c|}
\hline \multicolumn{14}{|c|}{ Length of core (mm) } \\
\hline & \multicolumn{6}{|c|}{ Seedlings } & \multicolumn{7}{|c|}{ Genotypes from repository Bacúch } \\
\hline \multicolumn{14}{|c|}{ Genotypes with low values } \\
\hline S10 & 30 & 10.10 & 12.70 & 11.24 & 9.24 & $\mathrm{~d}$ & $\mathrm{R} 31 / 2$ & 30 & 10.90 & 15.70 & 13.16 & 14.61 & $\mathrm{dc}$ \\
\hline S30 & 30 & 10.80 & 13.70 & 12.26 & 8.41 & $\mathrm{~d}$ & $\mathrm{R} 33 / 12$ & 30 & 11.40 & 14.50 & 13.42 & 8.84 & $\mathrm{dc}$ \\
\hline \multicolumn{14}{|c|}{ Genotypes with high values } \\
\hline S03 & 30 & 20.00 & 29.50 & 25.86 & 14.11 & $\mathrm{a}$ & $\mathrm{R} 3 / 2$ & 30 & 26.40 & 28.50 & 27.36 & 3.31 & $\mathrm{a}$ \\
\hline S47 & 30 & 18.50 & 25.60 & 22.06 & 11.67 & $\mathrm{a}$ & $\mathrm{R41/4}$ & 30 & 21.70 & 33.60 & 26.80 & 18.47 & $\mathrm{a}$ \\
\hline \multicolumn{14}{|c|}{ Diameter of core $(\mathrm{mm})$} \\
\hline & \multicolumn{6}{|c|}{ Seedlings } & \multicolumn{7}{|c|}{ Genotypes from repository Bacúch } \\
\hline \multicolumn{14}{|c|}{ Genotypes with low values } \\
\hline $\mathbf{S 2 2}$ & 30 & 0.94 & 1.08 & 1.01 & 4.35 & $\mathrm{c}$ & $\mathrm{R} 1 / 4$ & 30 & 17.50 & 19.00 & 18.26 & 3.60 & $\mathrm{~d}$ \\
\hline S76 & 30 & 0.98 & 1.03 & 1.00 & 1.54 & $\mathrm{c}$ & $\mathrm{R} 3 / 2$ & 30 & 17.10 & 20.10 & 18.52 & 6.89 & $\mathrm{~d}$ \\
\hline \multicolumn{14}{|c|}{ Genotypes with high values } \\
\hline S75 & 30 & 12.70 & 14.40 & 13.72 & 4.79 & $\mathrm{a}$ & $\mathrm{R} 20 / 8$ & 30 & 30.90 & 35.80 & 33.46 & 6.49 & $\mathrm{a}$ \\
\hline S47 & 30 & 13.20 & 16.30 & 14.98 & 7.70 & $\mathrm{a}$ & $\mathbf{R} 18 / 7$ & 30 & 26.20 & 30.30 & 28.42 & 5.46 & $\mathrm{~b}$ \\
\hline \multicolumn{14}{|c|}{ Index of fruit shape } \\
\hline & \multicolumn{6}{|c|}{ Seedlings } & \multicolumn{7}{|c|}{ Genotypes from repository Bacúch } \\
\hline \multicolumn{14}{|c|}{ Genotypes with low values } \\
\hline S02 & 30 & 0.69 & 0.79 & 0.74 & 4.48 & $\mathrm{ab}$ & $\mathrm{R} 1 / 4$ & 30 & 0.65 & 0.74 & 0.69 & 4.17 & $\mathrm{~b}$ \\
\hline S67 & 30 & 0.69 & 0.78 & 0.76 & 3.56 & $\mathrm{ab}$ & R7/7 & 30 & 0.68 & 0.72 & 0.70 & 1.49 & $\mathrm{~b}$ \\
\hline \multicolumn{14}{|c|}{ Genotypes with high values } \\
\hline $\mathbf{S} 22$ & 30 & 0.94 & 1.08 & 1.01 & 4.35 & $\mathrm{a}$ & $\mathrm{R} 41 / 4$ & 30 & 1.15 & 1.35 & 1.26 & 4.21 & $\mathrm{a}$ \\
\hline S76 & 30 & 0.98 & 1.03 & 1.00 & 1.54 & $\mathrm{a}$ & $\mathrm{R} 5 / 4$ & 30 & 0.97 & 1.25 & 1.09 & 6.60 & $\mathrm{ab}$ \\
\hline
\end{tabular}

Note: $\mathrm{n}$ - the number of measurements; min, max - minimal and maximal measured values; $\overline{\mathrm{x}}$ - arithmetic mean; $\mathrm{V}$ - coefficient of variation (\%); $\mathrm{H}$ - LSD homogeneity test at $\mathrm{P}_{0.05}$

descriptor, the fruits of seedlings can be characterized as small to large.

The average height of fruits of the genotypes under the study was in the range $41.43 \mathrm{~mm}(\mathrm{R} 33 / 12)-72.93 \mathrm{~mm}$ (R30/7)/29.55 mm (S12) - $74.04 \mathrm{~mm}$ (S22) and the diameter of fruits was in the intervals of $51.46 \mathrm{~mm}$ (R18/9) - $84.66 \mathrm{~mm}$ (R30/8)/36.85 mm (S12) $78.43 \mathrm{~mm}$ (S03). The collection of self-sown seedlings showed a significantly higher variation range in both evaluated traits. The coefficients of variation confirm the low or the medium degree of variability of the characters. Parameters are shown in table 2.

Jakobek et al. (2020) recorded heights (34-79 $\mathrm{mm}$ ) and diameters (41-89 $\mathrm{mm}$ ) of old varieties. The average height and diameter of old apple varieties cultivated in Bosnia and Herzegovina (Stanivuković et al., 2017) were recorded in the interval 50.08-67.21 mm and $53.52-80.23 \mathrm{~mm}$, respectively. Results showed by Božović et al. (2013) in Montenegro, where the intervals of evaluated traits were $42.29-64.70 \mathrm{~mm}$ and
$54.08-78.27 \mathrm{~mm}$ respectively, are similar to the data shown. Michálek (2003) states that from the market point of view, mainly varieties with medium to large fruits are in demand. Small or too large fruits are commercially unattractive. This customer requirement must be taken into account at assessing genotypes as a potential gene pool in breeding programs, as there are $19.5 \%$ of samples with small fruits (below $55 \mathrm{~mm}$ ) in our research collection.

An important diagnostic feature is the depth of stalk cavity and depth of eye basin, because the measured features may have a specific range for each variety and genotype. We determined the average depth of the stalk cavity in the collection of old and local varieties/ wild seedlings in the range of $1.67 \mathrm{~mm}(\mathrm{R} 22 / 3)$ $14.82 \mathrm{~mm}(\mathrm{R} 14 / 11) / 2.04 \mathrm{~mm}(\mathrm{~S} 24)-16.11 \mathrm{~mm}$ (S20). The results show that some fruits did not have stalk cavity (Table 2). We determined the average depth of eye basin in the collection of old and local varieties/ wild seedlings in the range of $2.10 \mathrm{~mm}$ (R18/9) - 8.86 mm (R3/16)/1.22 mm (S38) - 11.69 mm (S22). We 


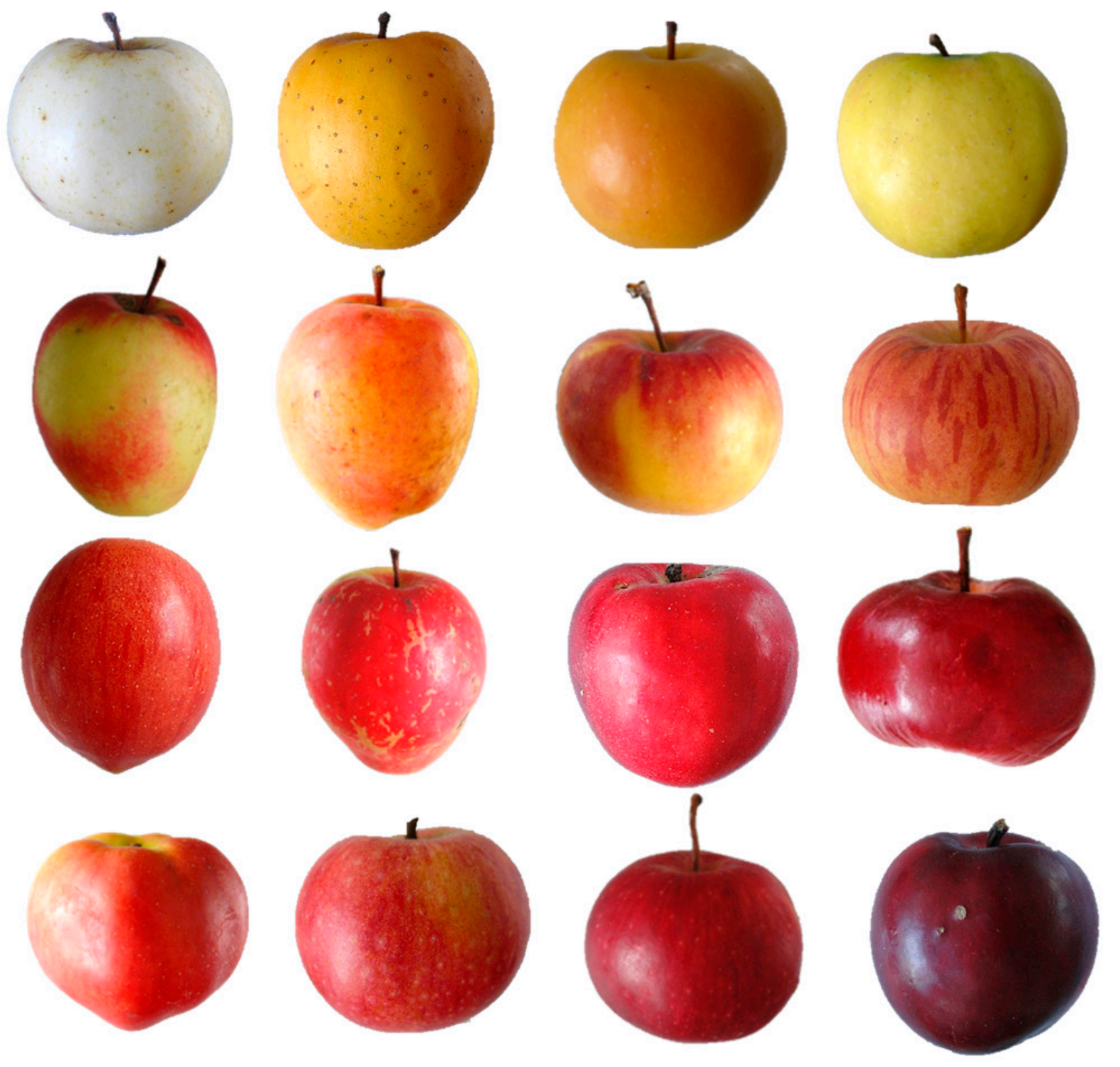

Figure 3 Variability in the shape and the colour of fruits of evaluated genotypes of seedlings of Malus domestica Borkh.

did not find any significant differences between the collections. The values of the coefficients of variation confirm the low or extremely high degree of variability of the traits.

Michálek (2003) distinguishes the shapes of the stalk cavity as narrow and shallow, wide and shallow, wide and deep, narrow and deep. In some varieties, a characteristic swollen formation is formed, which often overgrows and tilts the stalk to one side. We recorded a relatively large variability of the pomological feature (Figure 3). In the calyx part of the fruit, the shape, size and eye basin are important features. The depth of eye basin and its shape can be important because they are a little variable (Figure 4). According to Michálek (2003), we know the following eye basin: the small eye basin, the spacious eye basin, the short eye basin, the funnel eye basin, plumpness eye basin.

The average length of core of the genotypes under the study was in the range of $13.16 \mathrm{~mm}(\mathrm{R} 31 / 2)-$ $27.36 \mathrm{~mm}(\mathrm{R} 3 / 2) / 11.24 \mathrm{~mm}(\mathrm{~S} 10)-25.86 \mathrm{~mm}$ (S03), and diameter of core was in the range of $18.26 \mathrm{~mm}$ (R1/4) - $33.46 \mathrm{~mm}(\mathrm{R} 20 / 8) / 13.72 \mathrm{~mm}(\mathrm{~S} 75)$ - 30.86 $\mathrm{mm}$ (S3). We did not find any significant differences between the collections in the length and diameter of core, but diameters were relatively lower in the collection of wild seedlings. Coefficients of variation confirm the low or medium degree of variability of both characters. 

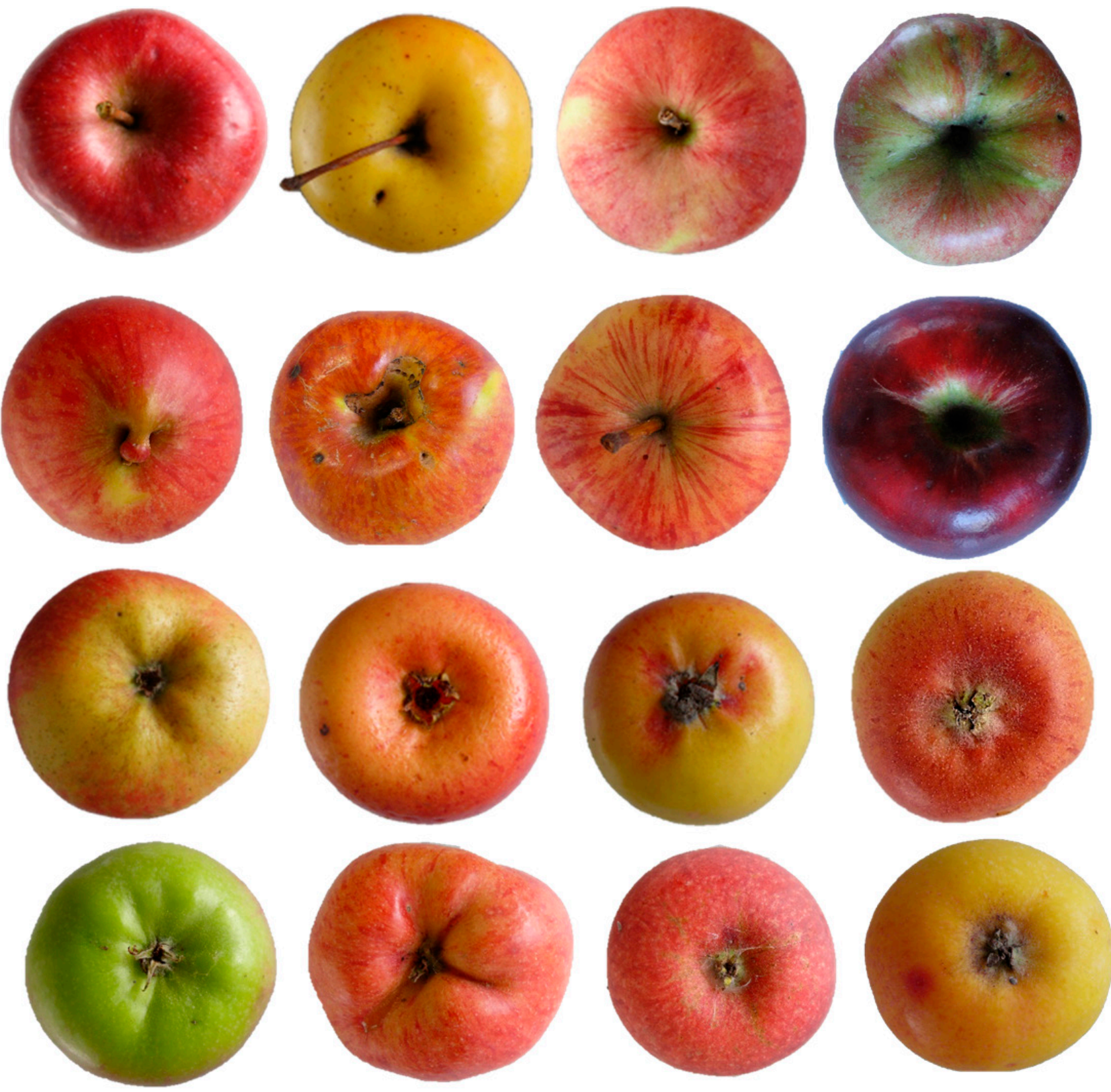

Figure 4 Variability in the characters of the depth of stalk cavity and depth of eye basin of the evaluated genotypes of the apple tree (Malus domestica Borkh.)

We determined the average value of the fruit shape index in the collection of old and local varieties and in the collection of wild seedlings. It is in the range from $0.69(\mathrm{R} 1 / 4)$ to $1.26(\mathrm{R} 41 / 4)$ and from $0.74(\mathrm{~S} 02)$ to 1.01 (S22). The comparison of genotypes with low and high values of the trait and variation ranges of the evaluated trait shows that genotypes with different values of the fruit shape index were determined in both collections. We did not find any significant differences between the collections. The coefficients of variation confirm the low degree of variability of the trait in both collections. Jakobek et al. (2020) recorded fruit shape index values (0.7-1.2) of old varieties.
The results from the analysis of variance of the evaluated traits (Table 3, Table 4) confirm the statistically significant differences between the evaluated genotypes.

Iqbal et al. (2011) described analytical methods tested in a laboratory for estimation of volume of axi-symmetric fruits like apples based on single view fruit images and the shape-based analytical models. The fruits are categorized into spherical, ellipsoid and paraboloid shapes with appropriate analytical models for their volume estimation. In both our collections of genotypes, spherical, elliptical and parabolic fruits are 
Table 3 Analysis of variance of evaluated fruit traits of genotypes of old and local varieties of Malus domestica Borkh. from the repository Bacúch

\begin{tabular}{|c|c|c|c|c|c|c|c|}
\hline Factors & $\mathbf{f}$ & $\mathbf{S}$ & MS & $\mathbf{F}$ & $\mathbf{H}$ & \multicolumn{2}{|c|}{ LSD } \\
\hline \multicolumn{8}{|c|}{ Weight of fruit (g) } \\
\hline Between genotypes & 9 & 124512.500 & 13834.720 & 137.226 & \multirow{2}{*}{0.000} & 0.05 & 14.447 \\
\hline Within genotypes & 90 & 9073.531 & 100.817 & & & 0.01 & 17.018 \\
\hline Total & 99 & 133586.031 & & & & & \\
\hline \multicolumn{8}{|c|}{ Height of fruit (mm) } \\
\hline Between genotypes & 9 & 4463.000 & 495.888 & 70.057 & \multirow{2}{*}{0.000} & 0.05 & 3.828 \\
\hline Within genotypes & 90 & 637.052 & 7.078 & & & 0.01 & 4.509 \\
\hline Total & 99 & 5100.052 & & & & & \\
\hline \multicolumn{8}{|c|}{ Diameter of fruit (mm) } \\
\hline Between genotypes & 9 & 5470.781 & 607.864 & 73.086 & \multirow{2}{*}{0.000} & 0.05 & 4.149 \\
\hline Within genotypes & 90 & 748535 & 8.317 & & & 0.01 & 4.888 \\
\hline Total & 99 & 6219.316 & & & & & \\
\hline \multicolumn{8}{|c|}{ Depth of stalk cavity ( $\mathrm{mm}$ ) } \\
\hline Between genotypes & 9 & 652.568 & 72.507 & 81.934 & \multirow{2}{*}{0.000} & 0.05 & 1.353 \\
\hline Within genotypes & 90 & 79.645 & 0.884 & & & 0.01 & 1.594 \\
\hline Total & 99 & 732.213 & & & & & \\
\hline \multicolumn{8}{|c|}{ Depth of eye basin (mm) } \\
\hline Between genotypes & 9 & 321.236 & 35.693 & 54.705 & \multirow{2}{*}{0.000} & 0.05 & 1.162 \\
\hline Within genotypes & 90 & 58.721 & 0.652 & & & 0.01 & 1.369 \\
\hline Total & 99 & 379.958 & & & & & \\
\hline \multicolumn{8}{|c|}{ Length of core (mm) } \\
\hline Between genotypes & 9 & 494.136 & 54.904 & 81.520 & \multirow{2}{*}{0.000} & 0.05 & 1.180 \\
\hline Within genotypes & 90 & 60.615 & 0.673 & & & 0.01 & 1.391 \\
\hline Total & 99 & 554.752 & & & & & \\
\hline \multicolumn{8}{|c|}{ Diameter of core (mm) } \\
\hline Between genotypes & 9 & 502.640 & 55.849 & 29.630 & \multirow{2}{*}{0.000} & 0.05 & 1.975 \\
\hline Within genotypes & 90 & 169.636 & 1.884 & & & 0.01 & 2.327 \\
\hline Total & 99 & 672.277 & & & & & \\
\hline
\end{tabular}

Note: $\mathrm{f}$ - number of degrees of freedom; $\mathrm{S}$ - the sum of squares; MS - average square; F - Fischer test value; P - statistical significance by Fischer test; $\mathrm{H}$ - homogeneity; LSD - a least significant difference 
Agrobiodivers Improv Nutr Health Life Qual, 5, 2021(1): 55-71

Table 4 Analysis of variance of evaluated fruit traits of seedlings of Malus domestica Borkh.

\begin{tabular}{|c|c|c|c|c|c|c|c|}
\hline Factors & f & $\mathbf{S}$ & MS & $\mathbf{F}$ & $\mathbf{H}$ & \multicolumn{2}{|c|}{ LSD } \\
\hline \multicolumn{8}{|c|}{ Weight of fruit (g) } \\
\hline Between genotypes & 9 & 247224.800 & 27469.420 & 50.756 & \multirow{2}{*}{0.000} & 0.05 & 33.472 \\
\hline Within genotypes & 90 & 48708.177 & 541.202 & & & 0.01 & 39.431 \\
\hline Total & 99 & 295932.990 & & & & & \\
\hline \multicolumn{8}{|c|}{ Height of fruit (mm) } \\
\hline Between genotypes & 9 & 11953.730 & 1328.193 & 65.014 & \multirow{2}{*}{0.000} & 0.05 & 6.503 \\
\hline Within genotypes & 90 & 1838.614 & 20.429 & & & 0.01 & 7.661 \\
\hline Total & 99 & 13792.348 & & & & & \\
\hline \multicolumn{8}{|c|}{ Diameter of fruit (mm) } \\
\hline Between genotypes & 9 & 12673.470 & 1408.163 & 83.695 & \multirow{2}{*}{-0.000} & 0.05 & 5.901 \\
\hline Within genotypes & 90 & 1514.241 & 16.824 & & & 0.01 & 6.952 \\
\hline Total & 99 & 14187.709 & & & & & \\
\hline \multicolumn{8}{|c|}{ Depth of stalk cavity (mm) } \\
\hline Between genotypes & 9 & 827.314 & 91.923 & 33.774 & \multirow{2}{*}{-0.000} & 0.05 & 2.373 \\
\hline Within genotypes & 90 & 244.951 & 2.721 & & & 0.01 & 2.796 \\
\hline Total & 99 & 1072.266 & & & & & \\
\hline \multicolumn{8}{|c|}{ Depth of eye basin (mm) } \\
\hline Between genotypes & 9 & 575.351 & 63.928 & 46.523 & \multirow{2}{*}{-0.000} & 0.05 & 1.686 \\
\hline Within genotypes & 90 & 123.668 & 1.374 & & & 0.01 & 1.986 \\
\hline Total & 99 & 699.019 & & & & & \\
\hline \multicolumn{8}{|c|}{ Length of core (mm) } \\
\hline Between genotypes & 9 & 1722.531 & 191.392 & 39.174 & \multirow{2}{*}{0.000} & 0.05 & 3.180 \\
\hline Within genotypes & 90 & 439.705 & 4.885 & & & 0.01 & 3.746 \\
\hline Total & 99 & 2162.237 & & & & & \\
\hline \multicolumn{8}{|c|}{ Diameter of core (mm) } \\
\hline Between genotypes & 9 & 1096.727 & 121.858 & 34.799 & \multirow{2}{*}{-0.000} & 0.05 & 2.692 \\
\hline Within genotypes & 90 & 315156 & 3.501 & & & 0.01 & 3.171 \\
\hline Total & 99 & 1411.883 & & & & & \\
\hline
\end{tabular}

Note: $\mathrm{f}$ - number of degrees of freedom; S - the sum of squares; MS - average square; F - Fischer test value; P - statistical significance by Fischer test; $\mathrm{H}$ - homogeneity; LSD - a least significant difference

most represented (Figure 3), which is in accordance with the literature data.

Apples may vary in colour, from uniformly dark-red, red, reddish, green, orange, yellow, white, or bi-coloured, such as striped or blushed red on a yellow or green background. Results have shown high variability of shapes and colours in both collections of Malus domestica.

The core of the fruit usually consists of five seed carpels pockets or carpels. Sometimes some fruits have only four or three carpels. Each pocket contains seeds. The number of seeds per carpel is determined by the vigour and health of the plant. Different varieties of apples will have a different number of seeds. Each carpel generally contains two seeds. Seeds are smooth, shiny, and chestnut brown (Jackson, 2003; Huff, 2012-2013).

The individual varieties are characterized not only by the shape of the core but also by its size and its location (Michálek, 2003). Figure 5 documents some differences in the shape of the core. On the cross-section, we can see 10 vascular bundles in a circle around the core. They seem like darker or lighter dots. In total, we can observe 10 vascular bundles, of which 5 are located directly opposite the tops of the carpels, the other 5 are between them. The vascular bundles determine the angularity of the fruit. If they are in a circle and evenly 

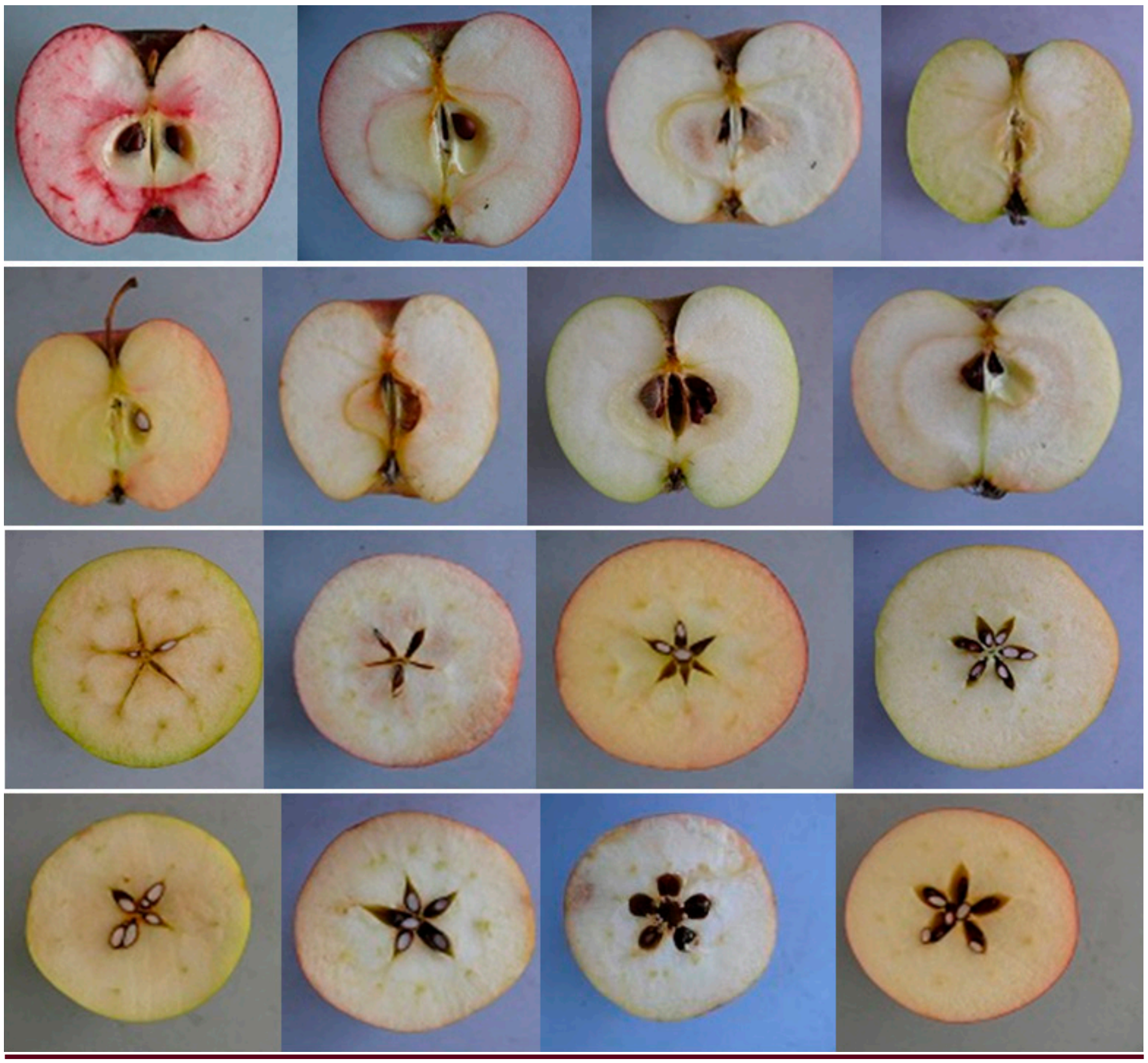

Figure 5 Comparison of selected genotypes from the evaluated collection of seedlings of Malus domestica Borkh. in the number of vascular bundles in the longitudinal and cross section

developed, the fruit is uniformly rotund in crosssection. If they are in two circles, the outer ones tend to be more developed and the fruit is thus become slightly angular (Kohout, 1960; Dvořák et al., 1976; Michálek, 2003). The examples on the presented photo (Figure 5) document that in the evaluated collection of genotypes has a relatively large variability of this pomological feature.

\section{Morphometrical analysis of seeds}

On the seeds, we evaluated the characteristics of the weight of 10 seeds $(\mathrm{g})$, the height of seeds $(\mathrm{mm})$ and the diameter of seeds $(\mathrm{mm})$. We determined the average weight of seeds in the genotypes under the study in the range from $0.38 \mathrm{~g}(\mathrm{R} 15 / 5)$ to $0.77 \mathrm{~g}(\mathrm{R} 41 / 1)$ and from $0.29 \mathrm{~g}$ (S28) to $0.98 \mathrm{~g}$ (S92). In the collection of wild seedlings, we recorded a higher range of variation in the evaluated trait. The coefficients of variation confirm the low or medium degree of variability of the trait. The average height of seeds for the collection of old and local varieties was in the range from $6.67 \mathrm{~mm}$ (R18/9) to $9.89 \mathrm{~mm}(\mathrm{R} 16 / 14)$ and for the collection of wild seedlings from $6.16 \mathrm{~mm}$ (S40) to $9.83 \mathrm{~mm}$ (S67). We did not find any significant differences between the collections. The coefficients of variation confirm the low degree of variability of the trait. We determined the 
Agrobiodivers Improv Nutr Health Life Qual, 5, 2021(1): 55-71

Table 5 Variability of seeds of old and local varieties and of wild seedlings of Malus domestica Borkh.

\begin{tabular}{|c|c|c|c|c|c|c|c|c|c|c|c|c|c|}
\hline \multicolumn{14}{|c|}{ Weight of seeds (g) } \\
\hline & \multicolumn{6}{|c|}{ Seedlings } & \multicolumn{7}{|c|}{ Genotypes from repository Bacúch } \\
\hline & $\mathbf{n}$ & $\min$ & $\max$ & $\overline{\mathbf{x}}$ & $\mathbf{V}$ & TH & & $\mathbf{n}$ & $\min$ & $\max$ & $\overline{\mathbf{x}}$ & $\mathbf{V}$ & TH \\
\hline \multicolumn{14}{|c|}{ Genotypes with low values } \\
\hline S28 & 30 & 0.24 & 0.40 & 0.29 & 15.38 & c & $\mathrm{R} 15 / 5$ & 30 & 0.34 & 0.41 & 0.38 & 5.79 & $\mathrm{~b}$ \\
\hline S12 & 30 & 0.25 & 0.36 & 0.30 & 13.20 & c & $\mathbf{R} 23 / 3$ & 30 & 0.36 & 0.42 & 0.39 & 5.17 & $\mathrm{~b}$ \\
\hline \multicolumn{14}{|c|}{ Genotypes with high values } \\
\hline S92 & 30 & 0.88 & 1.00 & 0.98 & 5.18 & a & $\mathbf{R 4 1 / 1}$ & 30 & 0.74 & 0.81 & 0.77 & 2.99 & a \\
\hline S89 & 30 & 0.85 & 1.00 & 0.93 & 7.14 & a & $\mathrm{R} 29 / 5$ & 30 & 0.72 & 0.76 & 0.74 & 1.78 & a \\
\hline \multicolumn{14}{|c|}{ Height of seeds (mm) } \\
\hline & \multicolumn{6}{|c|}{ Seedlings } & \multicolumn{7}{|c|}{ Genotypes from repository Bacúch } \\
\hline \multicolumn{14}{|c|}{ Genotypes with low values } \\
\hline S40 & 30 & 5.81 & 6.72 & 6.16 & 4.66 & c & $\mathrm{R} 18 / 9$ & 30 & 6.19 & 7.05 & 6.67 & 4.19 & $\mathrm{~b}$ \\
\hline S62 & 30 & 5.44 & 6.71 & 6.25 & 6.07 & c & R31/10 & 30 & 6.15 & 7.42 & 6.68 & 5.24 & $\mathrm{~b}$ \\
\hline \multicolumn{14}{|c|}{ Genotypes with high values } \\
\hline S67 & 30 & 9.06 & 10.63 & 9.83 & 5.58 & $\mathrm{a}$ & R16/14 & 30 & 9.24 & 10.56 & 9.89 & 4.85 & a \\
\hline S38 & 30 & 8.10 & 10.22 & 9.34 & 6.30 & $\mathrm{a}$ & $\mathrm{R} 27 / 11$ & 30 & 9.35 & 10.05 & 9.66 & 2.44 & a \\
\hline \multicolumn{14}{|c|}{ Diameter of seeds (mm) } \\
\hline & \multicolumn{6}{|c|}{ Seedlings } & \multicolumn{7}{|c|}{ Genotypes from repository Bacúch } \\
\hline \multicolumn{14}{|c|}{ Genotypes with low values } \\
\hline S82 & 30 & 3.02 & 3.96 & 3.51 & 7.88 & c & $\mathbf{R} 23 / 3$ & 30 & 3.23 & 4.05 & 3.73 & 7.55 & $\mathrm{c}$ \\
\hline S07 & 30 & 3.19 & 3.99 & 3.57 & 6.77 & c & $\mathbf{R} 41 / 4$ & 30 & 3.24 & 4.14 & 3.75 & 6.94 & c \\
\hline \multicolumn{14}{|c|}{ Genotypes with high values } \\
\hline S72 & 30 & 4.85 & 5.48 & 5.26 & 3.64 & $\mathrm{a}$ & $\mathrm{R} 5 / 4$ & 30 & 4.48 & 9.87 & 5.71 & 27.05 & $\mathrm{a}$ \\
\hline S89 & 30 & 4.66 & 5.47 & 5.08 & 4.37 & $\mathrm{a}$ & R19/12 & 30 & 4.51 & 7.79 & 5.63 & 20.93 & a \\
\hline \multicolumn{14}{|c|}{ Index of seed shape } \\
\hline & \multicolumn{6}{|c|}{ Seedlings } & \multicolumn{7}{|c|}{ Genotypes from repository Bacúch } \\
\hline \multicolumn{14}{|c|}{ Genotypes with low values } \\
\hline S62 & 30 & 1.17 & 1.41 & 1.35 & 5.26 & bc & R19/12 & 30 & 0.66 & 1.62 & 1.36 & 25.59 & $\mathrm{~b}$ \\
\hline S40 & 30 & 1.44 & 1.68 & 1.54 & 4.69 & $\mathrm{~b}$ & $\mathrm{R} 7 / 6$ & 30 & 0.55 & 1.88 & 1.45 & 32.58 & $\mathrm{~b}$ \\
\hline \multicolumn{14}{|c|}{ Genotypes with high values } \\
\hline S49 & 30 & 2.07 & 2.84 & 2.45 & 10.60 & a & $\mathrm{R} 27 / 11$ & 30 & 2.32 & 2.83 & 2.52 & 7.06 & a \\
\hline S19 & 30 & 1.88 & 2.62 & 2.28 & 10.57 & $\mathrm{a}$ & R16/12 & 30 & 2.11 & 2.71 & 2.43 & 7.77 & $\mathrm{a}$ \\
\hline
\end{tabular}

Note: $\mathrm{n}$ - the number of measurements; min, max - minimal and maximal measured values; $\overline{\mathrm{x}}$ - arithmetic mean; $\mathrm{V}$ - coefficient of variation (\%); $\mathrm{H}$ - LSD homogeneity test at $\mathrm{P}_{0.05}$ 

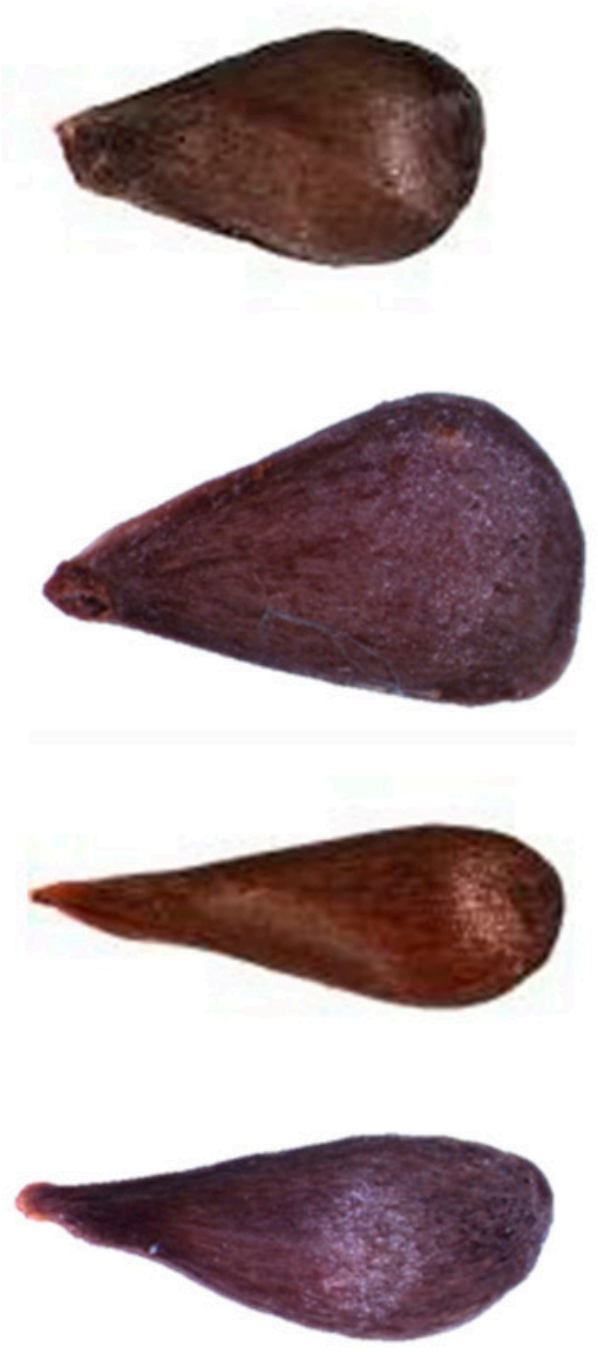
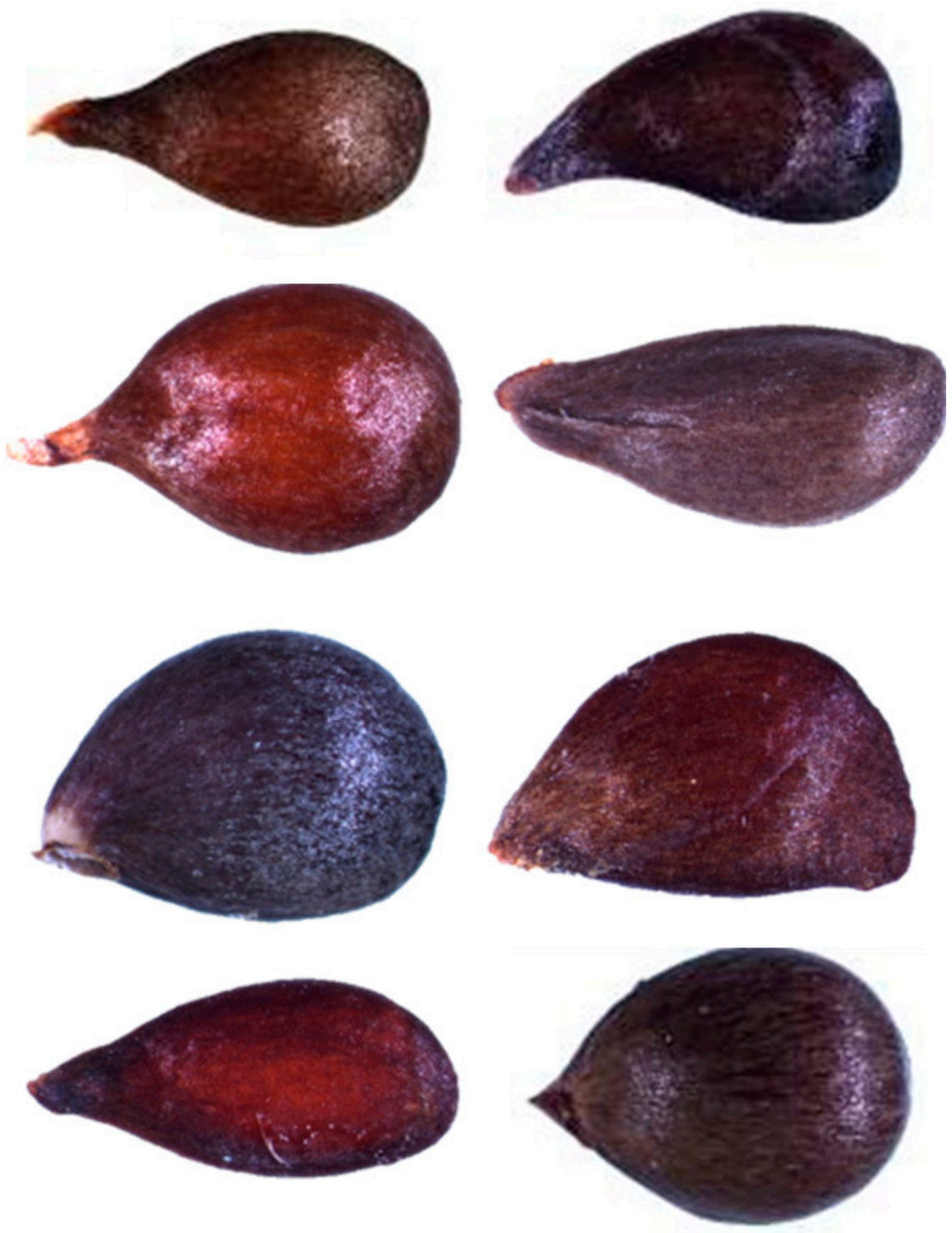

Figure 6

Comparison of selected genotypes from the evaluated collection of seedlings of Malus domestica Borkh. in the shape of seeds

average diameter of seeds in the collection of old and local varieties in the range $3.73 \mathrm{~mm}(\mathrm{R} 23 / 2)-5.71 \mathrm{~mm}$ (R5/4) and for the collection of wild seedlings $3.51 \mathrm{~mm}$ (S82) - $5.26 \mathrm{~mm}$ (S72). We did not find any significant differences between the collections. The coefficients of variation show that the degree of variability of this trait within both collections varies from low to high (Table 5). Our results do not diverge from the data of Jacobek et al. (2020), who estimated the weight of seeds in fruits from 0.07 to $0.53 \mathrm{~g}$, and the weight of a single seed from 0.03 to $0.08 \mathrm{~g}$.

We determined the average value of the seed shape index in the collection of old and local varieties in the range $1.36(\mathrm{R} 19 / 12)-2.52(\mathrm{R} 27 / 11)$ and in the collection of wild seedlings 1.35 (S62) - 2.45 (S49), respectively.
A comparison of genotypes shows that genotypes with different seed shape indices were identified in both collections. We did not find any significant differences between the collections. The coefficients of variation show that the degree of variability of this trait within both collections varies from low to high.

Figure 6 shows a comparison of selected genotypes from the evaluated collection of the natural seedlings of the apple tree (Malus domestica) in seed shapes.

The analysis of variance of the evaluated traits (Table 6) confirmed the statistically significant differences between the evaluated genotypes. 
Agrobiodivers Improv Nutr Health Life Qual, 5, 2021(1): 55-71

Table 6 Analysis of variance of evaluated seed traits of genotypes from two collections of Malus domestica Borkh.

\begin{tabular}{|c|c|c|c|c|c|c|c|}
\hline Factors & f & $\mathbf{S}$ & MS & $\mathbf{F}$ & $\mathbf{H}$ & LSD & \\
\hline \multicolumn{8}{|c|}{ Genotypes from repository Bacúch } \\
\hline \multicolumn{8}{|c|}{ Weight of 10 seeds (g) } \\
\hline Between genotypes & 9 & 0.888 & 0.098 & 42.074 & \multirow{2}{*}{0.000} & 0.05 & 0.069 \\
\hline Within genotypes & 90 & 0.211 & 0.002 & & & 0.01 & 0.082 \\
\hline Total & 99 & 1.099 & & & & & \\
\hline \multicolumn{8}{|c|}{ Height of seeds (mm) } \\
\hline Between genotypes & 9 & 78.918 & 8.768 & 24.898 & \multirow{2}{*}{0.000} & 0.05 & 0.853 \\
\hline Within genotypes & 90 & 31.696 & 0.352 & & & 0.01 & 1.005 \\
\hline Total & 99 & 110.614 & & & & & \\
\hline \multicolumn{8}{|c|}{ Diameter of seeds (mm) } \\
\hline Between genotypes & 9 & 16.238 & 1.804 & 10.330 & \multirow{2}{*}{0.000} & 0.05 & 0.601 \\
\hline Within genotypes & 90 & 15.718 & 0.174 & & & 0.01 & 0.708 \\
\hline Total & 99 & 31.957 & & & & & \\
\hline \multicolumn{8}{|c|}{ Seedlings } \\
\hline \multicolumn{8}{|c|}{ Weight of 10 seeds (g) } \\
\hline Between genotypes & 9 & 0.724 & 0.080 & 268.465 & \multirow{2}{*}{0.000} & 0.05 & 0.024 \\
\hline Within genotypes & 90 & 0.027 & 0.000 & & & 0.01 & 0.029 \\
\hline Total & 99 & 0.751 & & & & & \\
\hline \multicolumn{8}{|c|}{ Height of seeds (mm) } \\
\hline Between genotypes & 9 & 43.955 & 4.884 & 25.377 & \multirow{2}{*}{0.000} & 0.05 & 0.024 \\
\hline Within genotypes & 90 & 17.320 & 0.192 & & & 0.01 & 0.743 \\
\hline Total & 99 & 61.276 & & & & & \\
\hline \multicolumn{8}{|c|}{ Diameter of seeds (mm) } \\
\hline Between genotypes & 9 & 10.109 & 1.123 & 15.295 & \multirow{2}{*}{0.000} & 0.05 & 0.389 \\
\hline Within genotypes & 90 & 6.609 & 0.073 & & & 0.01 & 0.459 \\
\hline Total & 99 & 16.719 & & & & & \\
\hline
\end{tabular}

Note: $\mathrm{f}$ - number of degrees of freedom; $\mathrm{S}$ - the sum of squares; MS - average square; F - Fischer test value; $\mathrm{P}$ - statistical significance by Fischer test; $\mathrm{H}$ - homogeneity; LSD - a least significant difference

\section{Conclusions}

Based on morphometric analysis of fruits and seeds of both collection:

1. of old and local varieties,

2. of spontaneous seedlings from free pollination, we determined the range of phenotypic variability for all traits and combinations of traits in both groups of evaluated genotypes.

When comparing the ranges of variability for all evaluated traits, we found a significant degree of agreement. The results confirm that some individuals that grow wild and represent spontaneous seedlings from free pollination have a set of economically important traits and are ready to be used as potential genetic resources for a breeding program. Future efforts focused on "wild forms" should focus on preserving all unique genotypes to maintain both cultural heritage and biological genetic diversity.

\section{Acknowledgements}

This work was supported by the Bilateral Scholarship of the Ministry of Education, Science, Research and Sport, SAIA, and Visegrad Fund (Slovak Republic). Experimental activities were realized in the laboratories of the Centre of Excellence for the Conservation and Use of Agrobiodiversity at the Faculty of Agrobiology and Food Resources, Slovak Agricultural University in Nitra. The publication was prepared with the active participation of researchers involved in the International network AgroBioNet of the Institutions and researchers for the realization 
of research, education and development program «Agrobiodiversity for improving nutrition, health and life quality» and within the project ITEBIO - ITMS 26220220115.

\section{References}

BENEDIKOVÁ, D., GLASA, M., BENKOVÁ, M., SNAJDAR, N. 2016. Monitoring and preservation of old cherry cultivars in the Slovak Republic. In Acta Horticulturae, vol. 1139, p. 225-260. https://doi.org/10.17660/ActaHortic.2016.1139.39

BOČEK, S. 2008b. Old and regional varieties, their importance and use at present. [in Czech: Staré a krajové odrůdy, jejich význam a využití v současnosti]. In: Ovocné dřeviny $v$ krajině. Sborník přednášek a seminárních prací. Hostětín, pp. 7-19. ISBN 978-80-904109-2-3. [In Czech]

BOLVANSKÝ, M., UŽÍK, M. 2012. Variability of chestnut in selected localities of Slovakia. Biodiversity in agricultural landscape and ecosystem. In Proceedings of the International Congress REVERSE-INTERREG IVC. Pieštany : Research Institute of Plant Porduction, p. 44-47.

BOŽOVIĆ, D., JAĆIMOVIĆ, V., LAZOVIĆ, B. 2013. Old apple varieties in Central Montenegro. In Agriculture \& Forestry, vol. 59(2), p. 217-223.

BRINDZA, J. 2001. Ochrana genofondu rastlín. [Conservation of plant geen pool]. Nitra - Bratislava, 2001.143 s. ISBN 80-7137-974-3. [In Slovak]

BRINDZA, J., GRYGORIEVA, O., KLYMENKO, S., VERGUN, O., MAREČEK, J., IVANIŠOVÁ, E. 2019. Variation of fruits morphometric parameters and bioactive compounds of Asimina triloba (L.) Dunal germplasm collection. In Potravinarstvo Slovak Journal of Food Sciences, vol. 13(1), p. 1-7.

https://doi.org/10.5219/1019

BRINDZA, J., MOTYLEVA, S. et al. 2018. Pel' a včelie pel'ové obnôžky z niektorých druhov rastlín. [Pollen and bee pollen from certain plant species] 1. vyd., Nitra: Slovenská pol'nohospodárska univerzita, 134 s. ISBN 978-80-552-1862-5. [In Slovak]

DONNO, D.., BECCARO, G.L., MELLANO, M.G., TORELLO MARINONI, D., CERUTTI, A.K., CANTERINO, S., BOUNOUS, G. 2012.Application of sensory, nutraceutical and genetic techniques to create a quality profile of ancient apple cultivars. In Journal of Food Quality, vol. 35, p. 169-181. https://doi.org/10.1111/j.1745-4557.2012.00442

DOVBYSH, O.P., BORODAI, O.IU. 2011. Davni sorty yablun, shcho vyroshchuvalysia $\mathrm{V}$ Ukraini [Old varieties of apple trees cultivated in Ukraine] In: Dolatowski J., Piorecki A. (eds) Stare odmiany jabloni w dawnej Galicji Wschodniej. Bolestraszyce, p. 83-95. [In Ukrainian]

DVOŘÁK, A. et al. 1976. Jablka. [Apples]1. vyd. Praha : Academia, 592 s. ISBN 509-21-857. [In Czech]

FATRCOVÁ ŠRAMKOVÁ, K., BRINDZA, J., IVANIŠOVÁ, E., JURÍKOVÁ, T., SCHWARZOVÁ, M., HORČINOVÁ
SEDLÁČKOVÁ, V., GRYGORIEVA, O. 2019. Morphological and antiradical characteristics of Rugosa rose (Rosa rugosa Thunb.) fruits canned in different kind of honeys and in beverages prepared from honey. In Potravinarstvo Slovak Journal of Food Sciences, vol. 13(1), p. 497-506. https://doi.org/10.5219/1065

FELICIANO, R.P., ANTUNES, C., RAMOS, A., SERRA, A.T., FIGUEIRA, M.E., DUARTE, C.M.M., DE CARVALHO, A., BRONZE, M.R. 2010. Characterization of traditional and exotic apple varieties from Portugal. Part 1Nutritional, phytochemical and sensory evaluation. In Journal of Functional Foods, vol. 2, p. 35-45. https://doi.org/10.1016/j.jff.2009.12.004

GANOPOULOS, I., TOURVAS, N., XANTHOPOULOU, A., ARAVANOPOULOS, A., AVRAMIDOU, E., ZAMBOUNIS, A., TSAFTARIS, A., MADESIS, P., SOTIROPOULOS, T., KOUTINAS, N. 2017. Phenotypic and molecular characterization of apple (Malus x domestica Borkh.) genetic resources in Greece. In Scientia Agricola, vol. 75(6), p. 509-518.

http://dx.doi.org/10.1590/1678-992X-2016-0499

GRYGORIEVA, O., KLYMENKO, S., BRINDZA, J., SCHUBERTOVÁ, Z., NIKOLAIEVA, N., ŠIMKOVÁ, J. 2017a. Morphometric characteristics of sweet chestnut (Castanea sativa Mill.) fruits. In Potravinarstvo Slovak Journal of Food Sciences, vol. 11(1), p. 288-295. https://doi.org/10.5219/684

GRYGORIEVA, O., KLYMENKO, S., ILINSKA, A., BRINDZA, J. 2018a. Variation of fruits morphometric parameters of Elaeagnus multiflora Thunb. germplasm collection. In Potravinarstvo Slovak Journal of Food Sciences, vol. 12(1), p. 527-532.

https://doi.org/10.5219/922

GRYGORIEVA, O., KLYMENKO, S., VERGUN, O., HUDZ, N., NIKOLAIEVA, N., SCHUBERTOVÁ, Z., PALAMARCHUK, O., BRINDZA, J. 2017b. Morphological characteristics and determination of volatile organic compounds of Diospyros virginiana L. genotypes fruits. In Potravinarstvo Slovak Journal of Food Sciences, vol. 11(1), p. 612-622. https://doi.org/10.5219/808

GRYGORIEVA, O., KLYMENKO, S., VINOGRADOVA, Y., VERGUN, O., BRINDZA, J. 2018b. Variation in morphometric traits of fruits of Mespilus germanica L. In Potravinarstvo Slovak Journal of Food Sciences, vol. 12(1), p. 782-788. https://doi.org/10.5219/999

HARRIS, S. A., ROBINSON, J. P., JUNIPER, B. E. 2002. Genetic clues to the origin of the apple. In Trends in Genetics, vol. 18(8), p. 426-430.

HORČINOVÁ SEDLÁČKOVÁ, V., HULIN, M., BRINDZA, J. 2020. Comparison of old and landrace varieties of the apple tree (Malus domestica Borkh.) in the variability of some morphological characters of leaves and flowers. In Agrobiodiversity for Improving Nutrition, Health and Life Quality, vol. 4, p. 112-123. https://doi.org/10.15414/ agrobiodiversity.2020.2585-8246.112-123

HUFF, J. 2012-2013. Preservation and diversification of heirloom and antique apple varieties in Southern Ohio. Procejt Final Report FNC12-865, North Central, Ohio. 
HULIN, M., BRINDZA, J., TÓTH, D., HAJDU, Š., OSTROVSKÝ, R. 2012. Natural apple seedlings (Malus domestica Borkh.) as genetic resources for breeding new varieties. In Conservation of plant diversity. 1. vyd.540 s. Conservation of plant diversity. Chisinau: Academia de stiinte a Moldovei, p. 315-323. ISBN 978-9975-62-311-7.

IACOPINI, P., CAMANGI, F., STEFANI, A., SEBASTIANI, L. 2010. Antiradical potential of ancient Italian apple varieties of Malus $\times$ domestica Borkh. in a peroxynitrite-induced oxidative process. In Journal of Food Composition and Analysis, vol. 23(6), p. 518-524.

http://dx.doi.org/10.1016/j.jfca.2009.05.004

IQBAL, S. M., GOPAL, A., SARMA,A.S. V.2011. Volume estimation of apple fruits using image processing. In International Conference on Image Information Processing. https://doi.org/10.1109/iciip.2011.6108909

IVANIŠOVÁ, E., GRYGORIEVA, O., ABRAHAMOVÁ, V., SCHUBERTOVA, Z., TERENTJEVA, M., BRINDZA, J. 2017. Characterization of morphological parameters and biological activity of jujube fruit (Ziziphus jujuba Mill.). In Journal of Berry Research, vol. 7(4), p. 249-260. https://doi.org/10.3233/JBR-170162

JACKSON, J. E. 2003. Biology of apples and pears. Cambridge University Press, Cambridge.

JAKOBEK, L., IŠTUK, J., BULJETA, I., VOĆA, S., ŠIC ŽLABUR, J., SKENDROVIĆ BABOJELIĆ, M. 2020. Traditional, indigenous apple varieties, a fruit with potential for beneficial effects: Their quality traits and bioactive polyphenol contents. In Foods, vol. 9(52), p. 1-18. https://doi.org/10.3390/foods9010052

JUNIPER, B.E., MABBERLEY, D.J. 2006. The Story of the Apple. Timber Press : Portland, Oregon, USA.

KOHOUT, K. 1960. Jablka, malá pomologie [Apples, small pomology]. 1. Vyd. Praha: Státní zemědelské nakladatelství, 270 s. [In Czech]

KÜHN, B. F., ANDERSEN, T. T., PEDERSEN, H. L. 2003. Evaluation of 14 old unsprayed apple varieties. In Biological Agriculture \& Horticulture, vol. 20(4), p. 301-310. https:doi.org/10.1080/01448765.2003.9754975

KUZNETSOVA, E.A., EMELYANOV, A.A., VINOKUROV, A., BYCHKOVA, T., KLIMOVA, E.V., ZOMITEV, V., SELIFONOVA, N.A., BRINDZA, J. 2017. Antioxidant, antimicrobial activity and mineral composition of lowtemperature fractioning products of Malus domestica Borkh. (Common Antonovka). In Potravinarstvo Slovak Journal of Food Sciences, vol. 11(1), p. 658-663. https://dx.doi.org/10.5219/820

LEVON, V., GOLUBKOVA, I. 2019. The Contents of catechins and anthocyanins in the above-ground organs of plants of Prunus spinosa L. In Agrobiodiversity for Improving Nutrition, Health and Life Quality, vol. 3, p. 265-272. https://doi.org/10.15414/ agrobiodiversity.2019.2585-8246.265-272

MICHÁLEK, S., PAULEN, O., ONDREJIČKOVÁ, A., GLASA, M., BÁTOROVÁ, B. 2003. Jabloň. Biológia, pestovanie, využívanie [Apple tree. Biology, cultivation, utilization]. Nitra: SPU, 218 p. ISBN 80-8069-300-5. [In Slovak]
MiLiTARU, M., BUTAC, M., SUMEDREA, M., CĂLINESCU, M., MARIN, F.C. 2015. Evaluation of resistance to pests and diseases of some old apple varieties. In Fruit Growing Research, vol. XXXI, p. 34-37.

MITRE, I., MITRE, V., ARDELEAN, M., SESTRAS, R., SESTRAS, A. 2009. Evaluation of old apple cultivars grown in Central Transylvania, Romania. In Notulae Botanicae Horti Agrobotanici Cluj-Napoca, vol. 37(1), p. 235-237.

MONKA, A., GRYGORIEVA, O., CHLEBO, P., BRINDZA, J. 2014. Morphological and antioxidant characteristics of quince (Cydonia oblonga Mill.) and Chinese quince fruit (Pseudocydonia sinensis Schneid.). In Potravinarstvo Slovak Journal of Food Sciences, vol. 8, p. 333-340. https://doi.org/10.5219/415

MOTYLEVA, S. M., BRINDZA, J., ŠIMKOVÁ, J., HORČINOVÁ SEDLÁČKOVÁ, V. 2018. Comparative Study of morphometric characteristics and mineral composition of pollen Malus domestica Borkh. Agrobiodiversity for Improving Nutrition, Health and Life Quality, vol. 2, p. 285-291. https://doi.org/10.15414/ agrobiodiversity.2018.2585-8246.285-291

MOTYLEVA, S., BRINDZA, J., KULIKOV, I. 2017. The Morphology of pollen grains of the some species of Rosaceae Juss. family. In Agrobiodiversity for Improving Nutrition, Health and Life Quality, vol. 1, p. 338-341. http://dx.doi.org/10.15414/ agrobiodiversity.2017.2585-8246.338-341

OSZMIAŃSKI, J., LACHOWICZ, S., GAMSJÄGER, H. 2019. Phytochemical analysis by liquid chromatography of ten old apple varieties grown in Austria and their antioxidative activity. In European Food Research and Technology. https://doi.org/10.1007/s00217-019-03411-z

PAPP, D., KIRÁLY, I., TÓTH, M. 2015. Suitability of old apple varieties in organic farming, based on their resistance against apple scab and powdery mildew. In Organic Agriculture, 8 p. https://doi.org/10.1007/s13165-015-0126-2

PAPRSTEIN, F., SEDLAK, J. AND HOLUBEC, V. 2013. Rescue of Old Sweet Cherry Cultivars. In Acta Horticulturae, vol. 976, p. 227-230. https://doi.org/10.17660/ActaHortic.2013.976.29

POSOLDA, M., MLČEK, J., URBANOVÁ, M., ŘEZNÍČEK, V. 2019. Mapping of traditional and regional varieties of apple trees and pear trees in Kroměřiž area. In Acta Universitatis Agriculturae Et Silviculturae Mendelianae Brunensis, vol. 67(2), p. 425-434. https://doi.org/10.11118/actaun201967020425

ROBINSON, J. P., HARRIS, S. A., JUNIPER, B. E. 2001. Taxonomy of the genus Malus Mill. (Rosaceae) with emphasis on the cultivated apple, Malus domestica Borkh. In Plant Systematics and Evolution vol. 226, p. 35-58.

SEDOV, E.N. 2013. Results and prospects in apple breeding. In Universal Journal of Plant Science, vol. 1(3), p. 55-65. https://doi.org/10.13189/ujps.2013.010301

SOLOMATIN, N.M., SOLOMATINA, E.A., SOROKOPUDOV, V.N. 2017. Evaluation of fruits of red-flesh apple hybrids for 
the production of stewed fruit. Pomiculture and small fruits culture in Russia. In Plodovodstvo i âgodovodstvo Rossii, vol. 51, p. 312-317. ISSN 2073-4948

STANIVUKOVIĆ, S., ŽUJIĆ, M., ŽABIĆ, M., MIĆIĆ, N., BOSANČIĆ, B.,ĐURIĆ, G. 2017.Characterization ofOld AppleCultivars from Bosnia and Herzegovina by Means of Pomological and Biochemical Analysis. In Notulae Botanicae Horti Agrobotanici Cluj-Napoca, vol. 45(1), p. 97-104. https://doi.org/10.15835/nbha45110537

STEHLÍKOVÁ, B. 1998. Základy bioštatistiky [Fundamentals of biostatistics]. Učebné texty pre dištančné štúdium. Nitra: Ochrana biodiverzity. [In Slovak]

TÓTH, M., KÁSA, K., SZANI Z., BALIKÓ, E. 2004. Traditional Old Apple Cultivars as New Gene Sources for Apple Breeding. In XIth Eucarpia Symposium on Fruit Breeding \& Genetics, Eds. F. Laurens and K. Evans, In Acta Horticulturae, vol. 663, p. 609-612.

VELASCO, R., ZHARKIKH, A., AFFOURTIT, J., DHINGRA, A., CESTARO, A., KALYANARAMAN, A., FONTANA, P., BHATNAGAR, S. K., TROGGIO, M., PRUSS, D., others. 2010. The genome of the domesticated apple (Malus $\times$ domestica Borkh.). In Nature Genetics, vol. 42, p. 833-839.

VERGUN, O., RAKHMETOV, D., RAKHMETOVA, S., FISHCHENKO, V., SHYMANSKA, 0. 2020. Content of nutrients in different parts of Ipomoea batatas L. (Lam.). In Agrobiodiversity for Improving Nutrition, Health and Life Quality, vol. 4, p. 101-111. https://doi.org/10.15414/agrobiodiversit y.2020.2585-8246.101-111
VINOGRADOVA, YU., GRYGORIEVA, O., VERGUN, O., BRINDZA, J. 2017. Morphological characteristics for fruits of Aronia mitschurinii A. K. Skvortsov \& Maitul. In Potravinarstvo Slovak Journal of Food Sciences, vol. 11(1), p. 754-760. https://doi.org/10.5219/845

WOJDYŁO, A., OSZMIŃSKI, J., LASKOWSKI, P. 2008. Polyphenolic compounds and antioxidant activity of new and old apple varieties. In Journal of Agricultural and Food Chemistry, vol. 56, p. 6520-6530. https://doi.org/10.1021/if800510j

ŻYGALA, E., ANTONIEWSKA, E., LIB, D., PIORECKI, N. 2011. Inwentaryzacja i zachowanie starych odmian drzew owocowych w Dawnej Galicji Wschodniej [Inventory and conservation of old varieties of fruit trees in the ancient Eastern Galicia]. In: Dolatowski J., Piorecki A. (eds) Stare odmiany jabloni w dawnej Galicji Wschodniej. Bolestraszyce, p. 7-82. [In Poland] 